\title{
Kernos
}

Revue internationale et pluridisciplinaire de religion grecque antique

$34 \mid 2021$

Varia

\section{Revue des actes de colloques, ouvrages collectifs et anthologies}

\section{(2) OpenEdition}

\section{Journals}

\section{Édition électronique}

URL : https://journals.openedition.org/kernos/4095

DOI : $10.4000 /$ kernos.4095

ISSN : 2034-7871

\section{Éditeur}

Centre international d'étude de la religion grecque antique

\section{Édition imprimée}

Date de publication : 31 décembre 2021

Pagination : 323-332

ISBN : 978-2-87562-305-8

ISSN : 0776-3824

Référence électronique

"Revue des actes de colloques, ouvrages collectifs et anthologies », Kernos [En ligne], 34 | 2021, mis en ligne le 31 décembre 2021, consulté le 15 mars 2023. URL : http://journals.openedition.org/kernos/ 4095 ; DOI : https://doi.org/10.4000/kernos.4095

Ce document a été généré automatiquement le 15 mars 2023

Tous droits réservés 


\section{Revue des actes de colloques, ouvrages collectifs et anthologies}

1 Agócs Peter, PRAuscello Lucia (dir.), Simonides Lyricus: Essays on the 'Other' Classical Choral Lyric Poet, Cambridge, The Cambridge Philological Society, 2020 (Cambridge Classical Journal Proceedings of the Cambridge Philological Society Suppl. 42).

I. Rutherford, Simonides, Anius and Athens: PMG $537=301$ Poltera (Katheukai), p. 142-150 ;

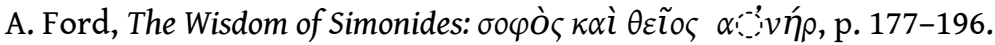

2 ALESSE Francesca, DE LUCA Ludovica (dir.), Philo of Alexandria and Greek Myth. Narratives, Allegories, and Arguments, Leiden/Boston, Brill, 2019.

E.S. Gruen, Philo's Refashioning of Greek Myth, p. 3-18 ; G. Roskam, Philo's Reception of Greek Mythology, p. 19-44 ; F. Calabi, Histoires grecques, récits bibliques. La lecture des mythes chez Philon d'Alexandrie, p. 45-71; G. Sfameni Gasparro, Polytheos doxa and Mythologein: Philo of Alexandria as a 'Historian of Religions', p. 72-106; E. Koskenniemi, The God of the Philosophers, and the God of Israel, p. 129-152 ; P. Nieto Hernández, Philo of Alexandria on Greek Heroes, p. 153-175 ; C.J.P. Friesen, Heracles and Philo of Alexandria: The Son of Zeus between Torah and Philosophy, Empire and Stage, p.176-199; B. Garstad, The Greek Character of Philo's Biblical Giants: A Reading of QG 2.82, p. 200-230 ; M. Alesso, Homer in Philo: Scylla's Myth in Philonic Philosophical Context, p. 231-251; L. Saudelli, Les 'plaies' d'Empédocle et la mythologie infernale chez Philon d'Alexandrie, p. 252-270.

3 Archimède 8 (2021) [dossier Siue Deus Siue Dea. Dénominations divines dans les mondes grec et sémitique : une approche par le genre].

C. Bonnet, Th. Galoppin, A. Grand-Clément, Que fait le genre aux dénominations divines, entre mondes grecs et sémitiques?, p.1-16; S. Georgoudi, Qu'est-ce qu'une "Grande" (Megalê) divinité en Grèce ancienne ?, p. 17-31; A. Vasselin, De la bonne manière de nommer Athéna à Athènes: l'emploi de hê theos dans les inscriptions athéniennes ( $\mathrm{VI}^{e}-I V^{e}$ siècles av. J.C.), p. 42-53 ; A. Kubiak-Schneider, Women in the Votive Dedications from Palmyra, p. 5464 ; M. Augier, Dénominations divines, genre des acteurs du rituel et des agents cultuels : le cas des prêtrises de Dionysos, p. 65-83.

Arys 17 (2019) [Vestir Divinamente. Deidades y Cultores Arropados o Desnudos]. 
J. Tomás García, Léxico, Usos y Espacios de las Imágenes de Culto en las Leyes Sagradas Griegas, p.13-35; J. Tello Benedicto, Ártemis del Quitón. Una Aproximación a su Culto en la Antigüedad, p. 37-63; V.Tsiolis, La Indumentaria Divina como Vehículo de Propaganda Política y Social. Reflexiones desde Arcadia, p. 65-83; D. Plácido Suárez, El travestismo de Penteo en los rituales dionisíacos, p. 85-103; G. Benedetti, Quando gli attributi travalicano il signum. Riflessioni sull'identità visuale degli dèi a Roma, p. 105-137 ; L. González Estrada, El atuendo de la Diosa. Identidad y Representación a través del Ejemplo de Juno Sospita, p. 139160 ; J. Alvar Ezquerra et al., La Vulva de Atis, p. 191-226 ; I. Campos Méndez, Un Dios que se Viste por los Pies: la Vestimenta Persa en la Iconografía Mitraica, p. 227-249 ; S. Corsi Silva, Heliogábalo Vestido Divinamente: a Indumentária Religiosa do Imperador Sacerdote de Elagabal, p. 251-276 ; A. de Miguel Irureta, J. Ramón Carbó García, La Pasarela de los Dioses. El Zeus de Olimpia y el Coloso de Rodas como Modelos Iconográficos Divinos en el Cristianismo, p. 277319 ; J.I. San Vicente González de Aspuru, Agustín y la Barba Dorada de Hércules, p. 321350.

Arys 18 (2020) [Begemann Elisabeth et al. (dir.), Rituals and Habitus in the Ancient World].

E. Begemann et al., Rituals and Habitus in the Ancient World. An Introduction, p. 13-17; F. Haussker, Suplicación de Niños en la Atenas clásica. Habilidades Religiosas, Supervivencia e Inferioridad, p. 95-122 ; R. Blankenborg, El Ritmo de la Voz de los Dioses. La Sugerencia de la Presencia Divina a través de la Prosodia, p. 123-154 ; B.S. Cassell, El Paisaje Ritual de Teseo. Apropiación, Identidad y Memoria Colectiva Ateniense, p. 213-255 ; R. Soneira Martínez, La vó бos de Declarar que los Dioses no Existen en las Leyes de Platón. ¿Casos Aislados o Grupos de

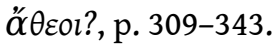

AURIGNY Hélène, DURVYE Cécile (dir.), Artémis près d'Apollon. Culte et représentation d'Artémis à Délos, Delphes, Claros et Didymes, Liège, Presses universitaires de Liège, 2021 (Kernos, Suppl. 37).

V. Pirenne-Delforge, En guise de préambule, p. 9-14; H. Aurigny et C. Durvye, Introduction, p. 15-30 ; C. Durvye, L'Artémis délienne dans la littérature antique, p. 31-60 ; J.Ch. Moretti, Les sanctuaires d'Artémis à Délos, p. 61-86; Cl. Sarrazanas, Les offrandes à Artémis d'après les inventaires déliens, p. 87-116; C. Durvye, J.-Ch. Moretti, Le culte d'Artémis dans les inscriptions de Délos, p. 117-136; A. Hermary, L'iconographie d'Artémis à Délos, p.137-164; C. Durvye, Synthèse: implantation et attributions d'Artémis à Délos, p.165-182; A.Perrier, L'Artémis delphienne dans les sources littéraires, p. 183-200; D. Laroche, Le temple d'Artémis à Delphes, p. 201-212 ; G. Rougemont, H. Aurigny, Artémis dans les inscriptions de Delphes, p. 213-220; H. Aurigny, Iconographie d'Artémis à Delphes, p. 221-240; A. Jacquemin, L'Artémis de Delphes et l'Artémis phocidienne, p. 241-250; H. Aurigny, Synthèse: Artémis à Delphes, une présence discrète, p. 251-262; R. Robert, Artémis à Claros : tradition littéraire, p. 263-270; N. Trippé, Artémis dans les inscriptions de Claros, p. 271-286; M. Dewailly, Les figurines de l'aire d'Artémis à Claros, p. 287-306; R. Robert, L'iconographie monumentale d'Artémis à Claros, p.307-322; H. Aurigny, C. Durvye, Synthèse : Artémis à Claros, un culte secondaire, p. 323-334; H. Bumke, Artémis Pytheiè à Didymes: réflexions sur la fonction et la signification de la déesse dans l'ombre du culte oraculaire 335-348; H. Aurigny, C. Durvye, Conclusion, p. 349-360.

7 BELAYCHE Nicole, ESTIENNE Sylvia (dir.), Religion et pouvoir dans le monde romain. L'autel et la toge. De la deuxième guerre punique à la fin des Sévères, Rennes, Presses universitaires de Rennes, 2020 (Histoire). 
C. Ando, Rites et religion, pluralisme et empire dans le monde romain, p. 55-74; J. Scheid, Les cultes étrangers à Rome. Voisins ou ennemis ?, p. 75-92 ; A.D. Rizakis, 'Symbiose', contacts et échanges transculturels à Philippes, colonie romaine en Macédoine orientale, p. 93-117.

BELAYCHE Nicole, MASSA Francesco (dir.), Mystery Cults in Visual Representation in GraecoRoman Antiquity, Leiden/Boston, Brill, 2020 (Religions in the Graeco-Roman World 194).

N. Belayche, Fr. Massa, Mystery Cults and Visual Language in Graeco-Roman Antiquity: an Introduction, p. 1-37 ; C. Isler-Kerényi, Comment figurer l'ineffable, comment lire les images ?, p. 43-61; S. Wyler, Le phallus qui cache le mystère? Les images dionysiaques dans les décors romains: à propos d'une fresque de la Domus Transitoria, p. 62-79; J. Balty, Échos de la Télétè dionysiaque dans la mosaïque romaine tardive, p. 80-98; R. Veymiers, Les mystères isiaques et leurs expressions figurées. Des exégèses modernes aux allusions antiques, p. 123168 ; A.-Fr. Jacottet, The Liknon and the Bundle: Does the Ritual 'Initiatory' Object Make the Mystery?, p. 173-193.

BENOIST Stéphane et al. (dir.), Mémoires de Trajan, mémoires d'Hadrien, Villeneuve d'Ascq, Septentrion, 2020 (Histoire et civilisations).

M. Kantiréa, De Trajan Zeus Philios au Panthéon d'Hadrien: enjeux politico-religieux et mémoires des Grecs et des chrétiens, p. 175-186.

BERLIN Andrea M., KOSMIN Paul J. (dir.), Spear-Won Land. Sardis from the King's Peace to the Peace of Apamea, Madison, The University of Wisconsin Press, 2019.

N. Cahill, Spotlight: The Metroön at Sardis, p. 91-95 ; F. Gallart Marqués, A Clay Kybele in the City Center, p. 120-131; F. Yegül, The Temple of Artemis, p. 132-138.

BONNET Corinne (dir.), Noms de dieux. Portraits de divinités antiques, Toulouse, Anacharsis, 2021 (Essais, Série « Histoire»).

C. Bonnet, "Aux Immortels tout est possible ». Portraits de dieux homériques, entre sauvagerie et empathie, p. 23-54; Th. Galoppin, Toutes les faces de la Lune. Une incantation grecque d'Égypte dans l'Antiquité tardive, p. 57-83; S. Lebreton, Dionysos au miroir de Poséidon: portraits onomastiques croisés, p.101-131; A. Kubiak-Schneider, Maître de l'Univers, du Monde et de l'Éternité : des dieux aux pouvoirs illimités à Palmyre?, p. 133-151; L. Bricault, Le glaive et la patère: Zeus Hélios grand Sarapis, p. 177-212; G. Benedetti, Pantheus, un dieu «total» dans le monde grec et romain, p. 235-255; A. Grand-Clément, Boucles d'Or chez les Grecs, ou les secrets capillaires du bel Apollon, p. 283-313; P. Brulé, Athéna - Artémis. Tentative d'esquisses de deux sœurs par leurs épiclèses mêmes, p. 315-361; Collectif, En guise d'épilogue: "Nous pensons, donc nous nommons» (Plutarque, Dialogue sur l'Éros, 759E), p. 363-369. BURIAN Peter, StRauss Clay Jenny, Davis Gregson (dir.), Euphrosyne. Studies in Ancient Philosophy, History, and Literature, Berlin/Boston, de Gruyter, 2020 (Beiträge zur Altertumskunde 370).

R. Sinos, Archilochos Heros and the Parian Relief, p. 112-169 ; K. Tsantsanoglou, Arsinoe and Mount Athos, p.170-180; F. Romer, Aphrodite $\Phi \iota \lambda$ i $\mu \mu \eta \delta \dot{\eta} \varsigma$ and Radical Gender Differentiation in an Ethnographic Myth, p. 183-208 ; J. Russo, The Ghost of Patroclus and the Language of Achilles, p. 209-222 ; D. Obbink, Kypri Despoina: Sappho's 'Kypris Poem' Reconsidered, p. 223-235 ; L. Hatzichronoglou, Cavafy's 'Interruption': The Ancient Myth, the Modern Poem and their Meaning for Us, p. 253-269. Universitaires de Liège, 2020 (Kernos, Suppl. 36). 
S.G. Caneva, Introduction: Rituals, Materiality, and the Cultic Honours for Hellenistic Political Leaders, p. 9-18 ; S.G. Caneva, L'importance de la matérialité. Le rôle des petits autels, plaques et bases inscrits dans la compréhension des cultes pour les souverains, p. 21-64; 0. Palagia, The Cult Statues of the Ptolemies and the Attalids, p. 65-81; S. Pfeiffer, Offerings and Libations for the King and the Question of Ruler-Cult in Egyptian Temples, p. 83-102; R. Strootman, Ch.G. Williamson, Creating a Royal Landscape: Hekatomnid Use of Urban and Rural Sacred Sites in Fourth-Century Karia, p. 105-124 ; M.C.D. Paganini, Cults for the Rulers in Private Settings: The Gymnasia and Associations of Hellenistic Egypt, p. 125-145 ; S.G. Caneva, Les honneurs cultuels pour Attale III à Pergame (IvP I 246), p. 147-164 ; C.C. Lorber, Who pays the Bill? Monetary Aspects of Royal Cult in the Ptolemaic Kingdom, p. 167-193; S.G. Caneva, L. Lorenzon, Les hymnes pour les chefs politiques dans les fêtes civiques. L'apport local à la construction des mythologies royales, p. 195-226 ; S.G. Caneva, Afterword, p. 227-239.

CECCONI Paolo, TORNAU Christian (dir.), Städte und Stadtstaaten zwischen Mythos, Literatur und Propaganda, Berlin/Boston, de Gruyter, 2020 (Beiträge zur Altertumskunde 383).

P. Cecconi, Ch. Tornau, Städte und Stadtstaaten zwischen Mythos, Literatur und Propaganda,

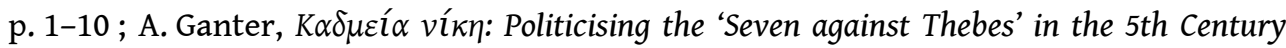
B.C, p.11-27; M. Meyer, Athen, Athena und die Athener. Identifikationsfigur(en) und Narrative, p. 29-74; V. Zetzmann, Von Argos nach Athen: Von Manipulation zu Polis-Rhetorik zwischen Aischylos' Agamemnon und Eumeniden, p. 75-106; P. Cecconi, 'Wer baute das siebentorige Theben?' Breve riflessione sulle origini della colpa e della catastrofe, p. 107-137 ;

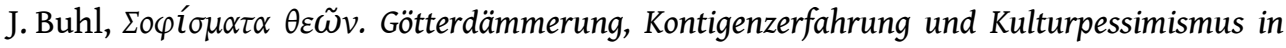
Euripides' 'Phönikierinnen', p. 139-162 ; M.P. Castiglioni, La metamorfosi di Cadmo nelle Baccanti di Euripide e il punto di vista ateniese, p. 163-179 ; P.J. Finglass, Phaedra between Homer and Sophocles: the Stesichorean Connexion, p. 181-190 ; J. Schultheiß, Plebs Argiva Thebana iuventus - verendi Cecropidae. Die 'kleinen Leute' in Statius' Thebais, p. 191222 ; S. Rocchi, Triptolemos und Europa in Tarraco. Stadtdarstellung, Politik und mythische Züge in Florus' Vergilius: orator an poeta?, p. 223-248 ; M. Hafner, Der 'Mythos Athen' im literarischen Diskursfeld fiktionaler Erzählprosa der Kaiserzeit. Lukian, Chariton und Heliodor, p. 249-267 ; C.O. Tommasi, Da indovino tebano a profeta universale. Alcune metamorfosi di Tiresia in età tardoantica, p. 269-292 ; Th. Gärtner, Ethopoiie, Struktur und Mythopoiie in den profanen Epyllien des Nordafrikaners Dracontius, p. 293-335.

CELENTANO Maria Silvana, NOËL Marie-Pierre (dir.), Images et voix du silence dans le monde gréco-romain/Immagini e voci del silenzio nel mondo greco-romano, Besançon, Presses universitaires de Franche-Comté, 2020 (Cahiers du Théâtre Antique. Cahiers du GITA 21. Nouvelle série. 3).

E. Medda, $M \alpha \theta \circ \tilde{v} \sigma \iota v \alpha \dot{U} \delta \tilde{\omega} \kappa o \dot{v} \mu \alpha \theta o \tilde{u} \sigma \iota \lambda \dot{\eta} \theta o \mu \alpha$. Fonctions dramatique du silence dans l'Agamemnon, p. 21-48 ; A.-I. Muñoz, Échos du silence dans l'Agamemnon d'Eschyle, p. 4980 ; A. Rodighiero, Silenzi imposti e silenzi 'parlanti' nelle Trachinie di Sofocle, p. 81-108; P. Demont, Silence, OEdipe! Le silence dans l'OEdipe à Colone de Sophocle, p. 109-122; M.S. Celentano, Le risorse della communicazione non verbale. A proposito di Hom. Il. 3, 216224 ; Eur. Hec. 334-341 ; Quint. Inst. 11, 3, 156-158, p. 237-246 ; C. Castelli, La 'poesia muta' dell'Ilias picta tra Omero e l'Andromaca di Euripide, 283-294 ; P. d'Alessandro, Il silenzio dei codici. Decorazioni misteriose, impertinenti, mancanti, p. 295-320.

CHAPELAIN DE SERÉVILLE Cécile et al. (dir.), Purifier, soigner ou guérir? Maladies et lieux religieux de la Méditerranée antique à la Normandie médiévale, Rennes, Presses Universitaires de Rennes, 2020 (Archéologie \& Culture). 
Chr. Delaplace, Des sanctuaires de guérison païens aux miracles de guérison des saints et des reliques dans l'Antiquité tardive : l'exemple de la Gaule ( $I V^{e}-\mathrm{VI}^{e}$ s.), p. 67-73; Th. Galoppin, Un lézard au coin de l'œeil: la puissance guérisseuse d'un animal ou de son image à l'époque romaine, p. 213-227; M. de Haro Sanchez, Médecine en magie et magie en médecine: antagonisme et complémentarité entre médecine rationnelle et médecine magique d'après les sources papyrologiques et littéraires gréco-latines, p. 229-240 ; É. Piguet, Pourquoi faire parler et agir Asclépios comme un technicien? Étude des représentations du malade, du dieu et de la guérison dans les récits de guérison d'Épidaure et de Lébèna, p. 255-265; P. Sineux, «Venir au sanctuaire", "venir vers le dieu en suppliant»: sur des expressions récurrentes et peu commentées des récits de guérison du sanctuaire d'Épidaure (IV ${ }^{e-I I I}$ S. av.J.-C.), p. 267-275; E. Samama, L'étuve et la sueur. Le bain d'air chaud dans les thermes romains et la pratique de la sudation dans le Corpus hippocratique, p. 277-286.

CHIARENZA Nicola, HAUG Annette, MÜLLER Ulrich (dir.), The Power of Urban Water. Studies in Premodern Urbanism, Berlin/Boston, de Gruyter, 2020.

N. Chiarenza, Water, Social Space and Architecture at Selinous: the Case of the Urban Sanctuary, p. 51-68; Ph. Kobusch, Fountains and Basins in Greek Sanctuaries. On the Relationship Between Ritual Performance and Architecture, p. 69-84.

collar Anna, KRISTENSEn Troels M., Pilgrimage and Economy in the Ancient Mediterranean, Leiden/Boston, Brill, 2020 (Religions in the Graeco-Roman World 192).

A. Collar, T.M. Kristensen, Embedded Economies of Ancient Mediterranean Pilgrimage, p. 130 ; A. Collar, Movement, Labour and Devotion: a Virtual Walk to the Sanctuary at Mount Kasios, p.33-61; H. Aurigny, Gathering in the Panhellenic Sanctuary at Delphi: an Archaeological Approach, p. 93-115 ; M. Horster, Hellenistic Festivals: Aspects of the Economic Impact on Cities and Sanctuaries, p.116-139; F.S. Naiden, The Monetisation of Sacrifice, p. 163-186 ; E. Eidinow, 'What Will You Give Me?': Narratives of Religious Exchange, p. 187203 ; T.M. Kristensen, Space, Exchange and the Embedded Economies of Greek Sanctuaries, p. 204-227 ; B. Kowalzig, Festivals, Fairs and Foreigners: Towards an Economics of Religion in the Mediterranean Longue Durée, p. 287-328; D. Padilla Peralta, Gods of Trust: Ancient Delos and the Modern Economics of Religion, p. 329-356.

constantakopoulou Christy, FRAGoulaki Maria, Shaping Memory in Ancient Greece: Poetry, Historiography, and Epigraphy, Newcastle upon Tyne, Histos, 2020 (Histos Supplement 11).

Chr. Pelling, Homer and the Question Why, p. 1-35; M. Fragoulaki, Thucydides Homericus and the Episode of Mycalessus (Thuc. 7.29-30): Myth and History, Space and Collective Memory, p. 37-86.

coşKUn Altay (dir.), Ethnic Constructs, Royal Dynasties and Historical Geography around the Black Sea Littoral, Stuttgart, Steiner, 2021.

J. Porucznik, Cult and Funerary Practices in Olbia and Its Chora. A Methodological Approach to the Study of Cultural Identity in Urban and Rural Communities, p. 45-74; A. Coşkun, Searching for the Sanctuary of Leukothea in Kolchis, p. 287-318.

21 DAVIS Brent, LAFFINEUR Robert (dir.), NESTEPOE. Studies in Bronze Age Aegean Art and Archaeology in Honor of Professor John G. Younger on the Occasion of His Retirement, Leuven/ Liège, Peeters, 2020.

D. Kokkinidou, In Pursuit of the Goddess: Neo-lithic Imagery, Marija Gimbutas, and Debates in Feminism and Archaeology, p.67-78; G. Vavouranakis, Liquid Consumption and the Mechanics of Ritual in Late Prepalatial and Old Palace Crete, p. 271-281. 
DE CESARE Monica, PORTALE Elisa Chiara, sojc Natascha (dir.), The Akragas Dialogue. New Investigations on Sanctuaries in Sicily, Berlin/Boston, de Gruyter, 2020.

N. Sojc, M. De Cesare, E.Ch. Portale, Introduction, p. 1-7 ; J. Wallensten, Closing in on the Gods. Indirect Communication Between Mortals and Immortals, p. 9-26 ; I. Patera, Identifier Déméter Thesmophoros et son culte en Sicile à partir des données matérielles, p. 27-57; A. Pautasso, Dedicants, Offerings, and Sacrifice. The Value of the Images, p. 59-78; M.C. Parello, Introduction to the Study of Sacred Spaces in Ancient Agrigento, p. 79-98; M. De Cesare, E.Ch. Portale, Il santuario di Zeus Olympios ad Agrigento: al di là del tempio monumentale, p. 99-124 ; F. Ducati, Sacelli dimenticati nell'area urbana di Akragas, p. 125131 ; M. Longo, Nuove considerazioni sul tempietto tripartito ad Est di Porta V, p. 133-148; A. Rheeder, Investigating the Terracotta Roofs of Akragas, p. 149-167; C. Genovese, The 'Upper Sanctuary of Demeter' at S. Biagio in Akragas: A Review, p. 169-200; A. Serra, Le offerte di manufatti bronzei nella pratica votiva agrigentina, p. 201-220 ; N. Sojc, Depositions of Sacrificial Material and Feasting Remains from the Extra-Urban Sanctuary of S. Anna (Agrigento). Appendix: A Note on Characteristic Finds by L. Adorno, p. 221-252 ; R. Miccichè, Sometimes Pigs Fly, p. 253-268; M. Albertocchi, Depositional Practices in the Bitalemi Sanctuary in the Archaic Period: Form and Interpretation, p. 269-289; F. Spatafora, Il santuario di Zeus Meilichios a Selinunte: Dati e materiali inediti per la rilettura del contesto, p. 291-313 ; C. Greco, I santuari di Demetra Malophoros e Zeus Meilichios a Selinunte: Le nuove indagini, p. 315-351 ; C. Marconi, The New Investigations of the Institute of Fine Arts-NYU in the Main Urban Sanctuary of Selinunte, p.353-370; E. Mango, New Evidence for Sacred Structures and Ritual Practices in Himera, Piano del Tamburino - Urbanistic Considerations, p. 371-397 ; M. Boglione, A Typology of Votive Offerings: Observations Regarding a Sacred Area on the Piano del Tamburino, Himera, p. 399-404 ; D. Leggio, Rites and Mysteries on the Acropolis of Akrai: Preliminary Remarks on a New Sanctuary Dedicated to the Cult of Demeter and Kore, p. 405-415.

DJIKSTRA Jitse H.F., RASCHLE Christian R., Religious Violence in the Ancient World. From Classical Athens to Late Antiquity, Cambridge, Cambridge University Press, 2020.

J.H.F. Djikstra, Ch.R. Raschle, General Introduction, p. 1-14; H.G. Kippenberg, Sacred Prefigurations of Violence: Religious Communities in Situations of Conflict, p.17-45; J.N. Bremmer, Priestesses, Pogroms and Persecutions: Religious Violence in Antiquity in a Diachronic Perspective, p. 46-68; E. Eidinow, Ancient Greek Binding Spells and (Political) Violence, p.71-86; W. Mayer, Religious Violence in Late Antiquity: Current Approaches, Trends and Issues, p. 251-265; P. Van Nuffelen, Coercion in Late Antiquity: A Brief Intellectual History, p. 266-285 ; J.H.F. Djikstra, Crowd Behaviour and the Destruction of the Serapeum at Alexandria in 391/392 ce, p. 286-305.

DORIA Federica, GIUMAN Marco (dir.), Eracle, Folo e la giara di Dioniso. Archeologia del vino in un episodio del mito, Rome, Giorgio Bretschneider, 2019 (Archaeologica 179).

M. Giuman, Storia di un infausto incontro nel racconto delle fonti scritte, p. 1-24 ; M. Giuman, Dioniso, vino, vita e morte, p. 25-51; F. Doria, Un passaggio per gli inferi, p. 53-69; M. Giuman, Archeologia di un mito celebre, p. 71-102 ; F. Doria, Il mito di Eracle e Folo nella ceramica attica, p. 103-118; F. Doria, Una bevanda pericolosa, p. 119-143.

FIGUEIRA Thomas, SOARES Carmen (dir.), Ethnicity and Identity in Herodotus, Londres/NewYork, Routledge, 2020.

G. Nagy, Mages and Ionians Revisited, p.109-142; A. Agnolon, Cosmopolitanism and Contingency in Herodotus: Myth and Tragedy in the Book IV of the Histories, p. 159-177; 
N.S. Rodrigues, A Goddess for the Greeks: Demeter as Identity Factor in Herodotus, p. 178-197 ; R. Gagné, Mirages of Ethnicity and the Distant North in Book IV of the Histories: Hyperboreans, Arimaspians, and Issedones, p. 237-257.

FORSÉN Jeannette, (dir.), Agios Elias of Assez, Arcadia. From Early Sanctuary to Medieval Village. Volume I, Stockholm, Swedish Institute at Athens, 2021 (Skrifter utgivna av Svenska Institutet $i$ Athen, $\left.4^{\circ}, 58: 1\right)$.

J. Forsén, Introduction, Aim, and Stratigraphy, p.13-32; J. Forsén, Protogeometric to Hellenistic Pottery, p.33-72; J. Forsén, Ceramic Finds Other than Pottery, p.73-78; L. Hammond, Miniature Vessels, p.79-88 ; C. MacKay, Medieval Pottery, p. 89-92 ; Ph. Sapirstein, Roof Tiles, p. 93-112 ; R. Frederiksen, Glass, p. 113-120 ; M. Alram, Coins, p.121-122 ; C. Lawton, Sculpture, p.123-124; J. Forsén, Miscellaneous Stone Objects, p. 125-126; E. Vila, Animal Sacrifice in Arcadia during the Archaic Period. The Faunal Remains from Agios Elias, p.127-152; A. Papathanasiou, Human Bones, p.153-160; J. Forsén, Conclusions, p. 161-164. FOSTER Margaret, KURKE Leslie, WEISS Naomi (dir.), Genre in Archaic and Classical Greek Poetry: Theories and Models. Studies in Archaic and Classical Greek Song, vol.4, Leiden/ Boston, Brill, 2020 (Mnemosyne. Suppl. 428).

G. Nagy, Genre, Occasion, and Choral Mimesis Revisited, with Special Reference to the 'Newest Sappho', p. 31-54 ; M. Foster, Athens and Apolline Polyphony in Bacchylides' Ode 16, p. 191228 ; M. Griffith, Is Korybantic Performance a (Lyric) Genre?, p. 231-270 ; M. Telò, Iambic Horror: Shivers and Brokenness in Archilochus and Hipponax, p. 271-297. FRIES Almut, KANELlakis Dimitrios (dir.), Ancient Greek Comedy. Genre - Texts - Reception. Essays in Honour of Angus M. Bowie, Berlin/Boston, de Gruyter, 2020 (Trends in Classics Suppl. 101).

A. Migliara, Imagining Space: Spatial Perception and the Gaze in Aristophanes' Birds, p. 133149 ; A. Markantonatos, Comic Pathways for Peace: Ritual Allegory and Choral Parabasis in Aristophanes' Lysistrata, p. 169-186 ; N. Tsoumpra, The Shifting Gender Identity of Dionysus in Aristophanes' Frogs, p. 199-215. G\&R 68 - Special Issue 1 (2021) [The Emotions of Medea].

E. Sander, The Emotions of Medea. An Introduction, p.1-7; D. Cairns, The Dynamics of Emotion in Euripides' Medea, p. 8-26 ; W. Allan, The Virtuous Emotions of Euripides' Medea, p. 27-44 ; E. Sanders, Love, Grief, Fear, and Shame. Medea's Interconnecting Emotions in Book 3 of Apollonius' Argonautica, p. 45-60 ; N. Michalopoulos, The Emotions of Medea the LetterWriter (Ovid, Heroides 12), p.61-75 ; P.A. Lima, Monstrous Emotions in Seneca's Medea, p. 76-96; Ch. Battistella, Medea and the Joy of Killing, p. 97-113. HAUG Annette, MERTEN Stephanie (dir.), Urban Practices. Repopulating the Ancient City, Turnhout, Brepols, 2020 (Studies in Classical Archaeology 8).

R.P. Krämer, Places of Gods and Men: Socio-Political Interactions and Ritual Practice in the Etruscan Sacred Landscape (Eighth to Fifth Centuries BC), p.115-135; S. Herzog, The Appropriation of Space in the Sanctuary of Poseidon at Isthmia, p.137-148; A. Müller, Hellenistic Built Space and Human Action: The Asclepieion of Cos, p. 149-165.

31 História: Questões \& Debates 69 (2021) [dossier Religiões na Grécia e Roma Antigas: Contatos, Encontros e Trocas].

I. Kourayos, K. Daifa, Despótiko: Escavações e Restauração de um Santuário de Apolo, p. 1846 ; E. Korka et al., Myths and Cults of Ancient Tenea, p. 47-80 ; M. Fowler, Of Human 
Sacrifice and Barbarity: A Case Study of the Late Archaic Tumulus XVII at Istros, p. 81-120 ; D. Katsonopoulou, The Cult of Poseidon Helikonios, p. 121-135 ; L. de Angelo Laky, Crotona e suas Conexões Religiosas e Políticas com Olímpia nos Séculos VI, V e IV a.C.: As Evidências das Imagens Monetárias de Águias e Raios, p. 136-162 ; P. Ellinger, Enlèvements de statues divines en bord de mer: de l'Artémis Taurique à Héra Reine, p. 163-182 ; L.M. Valletta, Héraclès et les Scythes dans la mémoire des Grecs de la mer Noire. Quelques réflexions sur Hdt. IV 8-10, p. 183211 ; R. Guimarães Tavares da Silva, T. Rennó Assunção, Archiloque et Dionysos autour de l'Égée, p. 241-270. hunt Ailsa, MARLow Hilary F. (dir.), Ecology and Theology in the Ancient World. CrossDisciplinary Perspectives, Londres, Bloomsbury Publishing, 2019.

D. Sedley, Self-Sufficiency as a Divine Attribute in Greek Philosophy, p. 41-48; Chr. Jedan, A Lighter Shade of Green: Stoic Gods and Environmental Virtue Ethics, p. 49-62 ; J. Wilberger, Cosmic Beauty in Stoicism: a Foundation for an Environmental Ethic as Love of the Other?, p. 63-74; R. Attfield, Some Ancient Philosophical and Religious Roots of Modern Environmentalism, p. 75-90 ; E. Bakola, Reconsidering the Chthonic in Aeschylus' Oresteia: Erinyes, the Earth's Resources, and the Cosmic Order, p. 103-118.

JACCOTTET Anne-Françoise (dir.), Rituels en image - Images de rituel. Iconographie - histoire des religions - archéologie, Berne, Peter Lang, 2021.

A.-Fr. Jaccottet, Représenter un rituel, représenter du rituel : en guise d'introduction, p. 7-20 ; Fr. Lissarague, Ce que l'image fait du rituel : variations attiques, p. 21-30 ; C. Isler-Kerényi, Le thiase dionysiaque: de la danse au cortège, p. 69-76; A. Verbanck-Piérard, Les scènes d'hommage à la divinité sur les vases attiques de la figure rouge tardive: ambiance de rituelsrituels d'ambiance?, p. 77-90; S. Huber, Des images au service des premiers rituels à Érétrie, p. 121-131; Chr. Mitsopoulou, Faisceaux et guirlandes, entre iconographie et réalité: images, gestes, rites et finances éleusiniennes, p. 133-154; H. Collard, Images et rituel, questions de méthode: l'exemple des pinakes de Locres, p. 173-188; J.-M. Pailler, Le trône bachique de Bolsena. De l'antre à la lumière, au cour d'un parcours rituel, p. 189-202; S. Estienne, Les Dioscures entre deux rivages. À propos du relief d'Argénidas, p. 203-214; A. Schnapp, Le rituel et le rôle des images dans la cité, p. 239-246; N. Belayche, Rituels en image - Images de rituel: quelques réflexions sur textes et images, p. 247-254.

KAIZER Ted (dir.), Religion, Society and Culture at Dura-Europos, Cambridge, Cambridge University Press, 2021 (Yale Classical Studies).

J.-B.Jon, Women and the Religious Life of Dura-Europos, p.99-113; J.Buchmann, Multifunctional Sanctuaries at Dura-Europos, p. 114-125 ; T. Gnoli, The Mithraeum of DuraEuropos: New Perspectives, p. 126-143.

KATSARou Stella, NAGel Alexander (dir.), Cave and Worship in Ancient Greece. New Approaches to Landscape and Ritual, Oxford/New-York, Routledge, 2021.

S. Katsarou, A. Nagel, Introduction: On Reading Caves and Ancient Greek Cult, p.1-16; S. Katsarou, The Dawn of Ancient Greek Cave Cult: Prehistoric Cave Sanctuaries, p. 17-48; N. Papalexandrou, Caves as Sites of Sensory and Cognitive Enhancement: The Idaean Cave on Crete, p. 49-69 ; C. Morgan, Chr. Hayward, Caves and Consumption: The Case of Polis Bay, Ithaca, p. 70-92 ; A. Karadima, Communities, Consumption and a Cave: The Profile of Cult at Drakaina Cave on Kephallonia, p.93-114; A. Nagel, A River Ran Through It: Circulating Images of Ritual and Engaging Communities in a Cave in Aitoloakarnania, p. 115-143; J.J. Bravo III, A. Mari, The Cave of Pan at Marathon, Attica: New Evidence for the Performance of Cult in the Historic Era, p. 144-166 ; K. Sporn, The Face of Cave Rituals: Terracotta Figurines 
in Greek Sacred Caves, p. 167-187 ; E. Angliker, Approaching Cult and Ritual in Cycladic Caves, p. 188-213 ; R. Miller Ammerman, Grottoes and the Construction of Cult in Southern Italy, p. 214-248.

KLOOSTER Jacqueline J.H. et al. (dir.), Callimachus Revisited. New Perspectives in Calimachean Scholarship, Leuven/Paris/Bristol, Peeters, 2019 (Hellenistica Groningana 24).

A. Harder, From Scamander to Demeter: Allusions to Homer in the Sixth Hymn of Callimachus, p. 121-145 ; J. Murray, Poetically Erect: The Female Oriented Humor in Callimachus' Hymn to Demeter, p. 249-263 ; F. Overduin, The Didactic Callimachus and the Homeric Nicander: Reading the Aetia Through the Theriaca?, p. 265-283; I. Petrovic, Poetry for the New Goddess: A Gift that Keeps on Giving, p. 285-303.

MACKIL Emily, PAPAZARKADAS Nikolaos (dir.), Greek Epigraphy and Religion. Papers in Memory of Sara B. Aleshire from the Second North American Congress of Greek and Latin Epigraphy, Leiden/Boston, Brill, 2021 (Brill Studies in Greek and Roman Epigraphy 16).

E. Mackil, N. Papazarkadas, Greek Epigraphy and Religion: Introduction, p.1-4; L. Gawlinski, Greek Religion and Epigraphic Corpora: What's Sacrae about Leges Sacrae?, p. 1126 ; J.-M. Carbon, Two Studies on the Epigraphy of Greek Sacrificial Butchery, p. 27-50 ; K. Takeuchi, IG I3 250, the Eleusinian Cults and Zeus Herkeios, p. 53-70 ; A.P. Matthaiou, Notes on the Decree on the Sacred Orgas (IG II3 1.292), p.71-89; S. Lambert, On the Conveyance of the Sacred Objects for the Eleusinian Mysteries: An Archaising Athenian Assembly Decree of the Third Century AD, p. 90-107 ; Y. Kalliontzis, An Inventory List and a Votive Relief from the Sanctuary of Artemis Brauronia Found in Oropos, p. 108-163; A. Makres, Victorious Athletes of Ancient Messene: Old and New Epigraphic Evidence, p. 167203 ; E. Martín González, Divine Utterances: Answers on the New Oracular Tablets from Dodona, p. 204-226 ; M. Mili, J. Wallensten, Dedications from the Dead? The Strange Case of Hermes Chthonios, p. 227-247 ; A.C. Scafuro, Koan Good Judgemanship: Working for the Gods in IG XII.4.1 132, p. 248-282 ; G.E. Malouchou, The Chian Sacred Law of Parparia Revisited, p. 283-294; F.S. Naiden, The Self-Definition of Alexander the Great, p. 295-309; M. Zellmann-Roher, Tantalus and Hemorrhage: An Inscribed Hematite Gem and Its Tradition, p. 310-334.

MARSHAll Hallie, MARSHALl C.W. (dir.), Greek Drama V. Studies in the Theatre of the Fifth and Fourth Centuries BCE, Londres, Bloomsbury Publishing, 2021 (Bloomsbury Classical Studies Monographs).

Sh. Murnaghan, Selective Memory and Epic Reminiscence in Sophocles' Ajax, p. 23-36; E. Papazoglou, A Dramaturgy of the Self: Deianira Between the Grid and the Couch, p. 47-60 ; J. Gibert, Tragic Overliving and Deferred Funerary Ritual in Euripides' Hecuba, p. 61-72 ; R. Lionetti, The Fall of Troy, the Glory of Athens: Chorus and Community in Euripides' Trojan Women, p. 87-100 ; A. Stavroula Valtadorou, Erôs in Pieces (?): Tragic Erôs in Euripides' Andromeda and Antigone, p.115-128; A. Simas, Aeschylus and the Iconography of the Erinyes, p. 145-160 ; P.G. Johnston, The Women of Thebes as Aeschylean Erinyes: the First Messenger Speech of Euripides' Bacchae, p. 161-172 ; B.M. Rogers, Electra-style: Reception(s) of Aeschylus' Oresteia in Aristophanes' Clouds, p. 173-188.

MASTROCINQUE Attilio, SANZo Joseph E., sCAPINI Marianna (dir.), Ancient Magic. Then and Now, Stuttgart, Franz Steiner Verlag, 2020 (Potsdamer Altertumswissenschaftliche Beiträge, 74).

J.E. Sanzo, Deconstructing the Deconstructionists: a Response to Recent Criticisms of the Rubric "Ancient Magic", p.27-48; A. Alvar Nuño, J.Alvar Ezquerra, "Pure Magic" and its 
Taxonomic Value, p.49-62; F. Diosono, Lamps as Ritual and "Magical" Objects in Archaeological Contexts, p. 139-158 ; V. Dasen, Play With Fate, p. 173-192 ; Ch.A. Faraone, The Use of Divine Images in the Dream-Divination Recipes of the Greek Magical Papyri, p. 193210 ; E. Suárez de la Torre, Women as Users of Erotic Spells: Evidence Provided by Papyri and Defixiones, p. 211-232 ; I. Canzobre Martínez, Remarks on the Categorisation of the Divine in the PGM, p. 233-256 ; M. Blanco Cesteros, The Paradox of a "Magical Hymn": Reviewing the Poetic Compositions of the Greek Magical Papyri, p. 257-286 ; G. Pedrucci, On the Use of Breast Milk and Menstrual Blood in the Greek and Roman Worlds, p. 287-314 ; A. Pérez-Jiménez, Importancia de la oposición derecha/izquierda en la magia y la astrología, p.315-332; R. Martín Hernández, The Transmission of the Sortes Homericae. A Papyrological Approach to the Texts, p. 375-386 ; S. Costanza, Dottrina magica nei manuali divinatori greci, bizantini $e$ metabizantini, p. 386-404; M. Foschi Albert, Magic Potions, Homeric Cunning and Jason's Charm: Magic Motifs in Gottfried von Strassburg's Middle High German Version of the Tristan Legend, p. 405-414; T. Dorandi, Considerazioni sull'ecdotica dei testi magici antichi alla luce del PLeid. J 395 (PGM XIII), p. 415-424 ; C.M. Lucarini, La prima apparizione di Circe nella letteratura greca e il fantasma dell'epos argonautico pre-odissiaco, p. 425-451.

Mètis 18 (2020) [dossier Des femmes qui comptent. Genre et participation sociale en Grèce et à Rome \& Varia].

A. Gartziou-Tatti, L'implication religieuse des femmes nommées dans le sanctuaire de Dodone, p. 83-102; Entretien avec Pauline Schmitt Pantel et Stella Georgoudi: Deux hellénistes et l'histoire des femmes, p. 137-148; K.W. Yu, Beyond Grand Theories and Family Resemblances. Toward a Discursive Approach to Greek Sacrifice, p.151-177; C. Marcaccini, Eupolis, Alcibiade et la profanation des Mystères éleusiniens, p.179-196; D. Angileri, La metis di Perseo e Dedalo sull'oinochoe di bucchero della collezione Casuccini, p. 221-231; M. Pierre, La tragédie sans drame. Relire la Médée de Sénèque à partir du nō, p. 251-270.

Mythos 14 (2020) [KIMMEL-CLAUZET Flore, MUCCIOLI Federicomaria (dir.), Devenir un dieu, devenir un héros en Grèce ancienne/Diventare un dio, diventare un eroe nel mondo greco, en ligne].

N. Cusumano, In ricordo di Federicomaria Muccioli; Fl. Kimmel-Clauzet, Introduction; Fl. Frisone, Eracle in Magna Grecia: una porta verso l'eroizzazione?; G. Ingarao, Denominare un dio, denominare un eroe. Erodoto e i 'due Eracle'; M. Nafissi, Gli eroi del Trono di Apollo ad Amicle. Tra apoteosi, immortalità elisia e destino di morte ; T. Mojsik, The "Double Orpheus": between Myth and Cult ; Chr. Mauduit, La fin mystérieuse d'ÆEdipe dans l'ÆEdipe à Colone de Sophocle: aspects religieux et enjeux dramatiques d'une héroïsation; S. Gotteland, Honorés à l'égal des dieux et des héros? La célébration des bienfaiteurs de la démocratie chez les orateurs attiques; V. Visa-Ondarçuhu, "Athlète" pour les uns, "athlète-héros" pour d'autres : analyse critique des sources; Fl. Kimmel-Clauzet, Theios Homèros: du poète inspiré au poète divinisé ?; M. Haake, Städtische Philosophenkulte in der griechischen Welt zwischen Archaik und Hellenismus - Fakten und Fiktionen; S. Grau, Cultos a filósofos griegos antiguos en Diógenes Laercio: evidencias y funciones ; S.G. Caneva, A. Coppola, Hērōs ed hērōikai timai nel mondo greco ellenistico e imperiale: semantica e prassi, attori e contesti; Br. Currie, Aristophanes and the Cult of the Saviour; G. Camassa, Soter e soteria dal V secolo alle soglie dell'età ellenistica: qualche considerazione; F. Muccioli, Tradizione e innovazione cultuale in

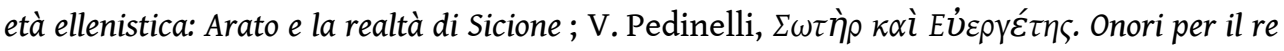
Antigono Dosone tra innovazione e rispetto della tradizione antigonide; K. Buraselis, On Greek Intellectuals and the Roman Emperor Cult ; D. Bonanno, 'La chiamiamo con entrambi i nomi': eponimia ed eteronimia tra Nemesis e Adrasteia. 


\section{Architecture and Function in Ancient Greek Sanctuaries in Honour of Richard Alan Tomlinson,} Oxford, Archaeopress, 2019.

N. Th. Katsikoudis, The Stoas of the Sanctuary at Dodona, p. 29-37 ; F. Lang, Architectural Practice and the Distinctiveness of Sacred Sites, p. 38-53; S. Dietz, Town and Sanctuary in Aetolia - Calydon in Context, p. 54-64 ; E.C. Partida, Politics Reflected on Architecture: an Evaluation of the Aetolian, the Pergamene and the Roman Input to the Religious Landscape at Delphi, p. 65-79 ; M. Germani, From the Valley of the Muses via the Kabeirion of Thebes to the Ptoion: The Theatres and Sanctuaries of Boetia, p. 80-87 ; D. Katsonopoulou, Observations on the History and Topography of Two Major Sanctuaries of Poseidon and Zeus in Aigialeia of Achea, p. 88-97 ; D.G. Romano, The Organization, Planning and Architectural Design of the Sanctuary of Zeus at Mount Lykaion, Arcadia, p. 98-108; J. Pakkanen, Reconstructing Building Height: The Early Hellenistic Hestiatorion Propylon at Epidauros, p.109-120; D. Egglezos, Interpretation of the Current State of the Treasuries Retaining Wall at Ancient Olympia through Staged Historical Back Analysis, p. 121-138; G. Doulfis, Sacred Architecture in Roman Laconia, p. 139-152 ; B.D. Wescoat, More Corinthian on Samothrace, p. 153161 ; Y. Kourtzellis, The Sanctuaries on the Island of Lesbos from an Architectural and Topographical Perspective, p.162-181; L.A.Beaumont, Shaping the Ancient Religious Landscape at Kato Phana, Chios, p. 182-190 ; G. Rocco, Topographical Study of Ancient Cos: New Data from the Western District, p.191-201; M. Livadiotti, The Tufa Stoa in Cos: a Hypothesis on Its Identification, p. 202-213 ; L.M. Caliò, Medicine, Urbanisation and Religion in Classical Cos, p. 214-222 ; F. Hulek, Temple and Hestiatorion. The Combined Edifice on Mount Çatallar Tepe (Turkey), p. 223-232.

REBENICH Stefan, WIEMER Hans-Ulrich (dir.), A Companion to Julian the Apostate, Leiden/ Boston, Brill, 2020 (Brill's Companions to the Byzantine World 5).

H.-U. Wiemer, Revival and Reform: The Religious Policy of Julian, p. 207-244 ; Ch. Riedweg, Anti-Christian Polemics and Pagan Onto-Theology: Julian's Against the Galilaeans, p. 245266 ; A. Marcone, Pagan Reactions to Julian, p. 326-359.

SCHACHTER Albert, Boiotia in Antiquity. Selected Papers, Cambridge, Cambridge University Press, 2021. 
Pausanias and Boiotia, p. 133-148; The Politics of Dedication: Two Athenian Dedications at the Sanctuary of Apollo Ptoieus in Boiotia, p. 151-167; The Seer Tisamenos and the Klytiadai, p. 168-172; Gods in the Service of the State: the Boiotian Experience, p.175-192; The Daphnephoria of Thebes, p. 255-278 ; Reflections on an Inscription from Tanagra, p. 279288 ; Egyptian Cults and Local Elites in Boiotia, p. 289-314; Evolutions of a Mystery Cult: the Theban Kabiroi, p. 315-343 ; The Mouseia of Thespiai: Organization and Development, p. 344371 ; Tilphossa: the Site and its Cults, p. 273-380 ; A Consultation of Trophonios (IG 7.4136), p. 381-391.

SCHOWALTER Daniel et al. (dir.), Religion in Ephesos Reconsidered. Archaeology of Spaces, Structures, and Objects, Leiden/Boston, Brill, 2020 (Supplements to Novum Testamentum 177).

Th. Schulz, The So-called Serapeion in Ephesos: First Results of the Building Research, p. 4161 ; H. Thür, Sacred Space for Dionysos in Ephesos and the House of C.Fl. Furius Aptus, p. 135157 ; L. Zabrana, The Artemision in the Roman Era: New Results of Research within the Sanctuary of Artemis, p. 158-170 ; Fr. Kirbihler, Ruler Cults and Imperial Cults at Ephesos: First Century BCE to Third Century CE, p. 195-210 ; N. Zimmermann, Archaeological Evidence for Private Worship and Domestic Religion in Terrace House 2 at Ephesos, p. 211-229; E. Rathmayr, The Meaning and Use of Terracotta Figurines in the Terrace Houses in Ephesos, p. 230-251. SCHRAMM Michael (dir.), Euripides-Rezeption in Kaiserzeit und Spätantike, Berlin/Boston, de Gruyter, 2020 (Millenium-Studien 83).

Th.A. Schmitz, Euripides' Bacchae in Nonnus' Dionysiaca, p. 239-255 ; L. Krauss, Maria, die Medea, die Bakchen und der Rhesos: Beispiele für die Euripides-Rezeption im Christus patiens, p. 391-414.

WAGNER-EGELHAAF Martina, QUAST Bruno, BASU Helene (dir.), Mythen und Narrative des Entscheidens, Göttingen, Vandenhoeck \& Ruprecht, 2020 (Kulturen des Entscheidens 3).

B. Zimmermann, Krisis. Entscheidungen im griechischen Mythos, p. 63-72 ; M. Grünbart, Das Paris-Urteil im griechischen Mittelalter, p. 73-92 ; A. Baehr-Oliva, Die Aufwertung des ParisUrteils in barocken Musikdramen, p. 93-111; H. Haferland, Gunnars exorbitante Entscheidung im alten 'Atlilied', p.112-138; A. Musio, Zwischen Mythos und Philosophie. Orpheus' Entscheidung, p. 141-138.

\section{Contributions particulières}

CAMBIANO G., "Astronomy and Divination in Stoic Philosophy", in A.C. BOWEN, Fr. ROCHBERG (dir.), Hellenistic Astronomy. The Science in Its Contexts, Leiden/Boston, Brill, 2020, p. 607-618.

DOROSZEWSKI F., «Dieu rejeté, Dieu triomphant. Réception des Bacchantes d'Euripide dans la Paraphrase de l'Évangile de Saint Jean de Nonnos de Panopolis », in M. Cutino (dir.), Poetry, Bible and Theology from Late Antiquity to the Middle Ages, Berlin/Boston, de Gruyter, 2020, p. 151-159.

GoURMelen L., "Thésée et les Amazones (Plutarque, Vie de Thésée, 26-28). Mythe et histoire: construction d'un récit biographique », in P. MARÉchAUX, B. MINEO (dir.), Plutarque et la construction de l'Histoire. Entre récit historique et invention littéraire. Actes du 
colloque organisé les 13 et 14 mai 2016 à l'université de Nantes, Rennes, Presses universitaires de Rennes, 2020 (Histoire), p. 105-125.

HAYSOM M., "Religion and Cult », in I.S. LEMOS, A. KOTSONAS (dir.), A Companion to the Archaeology of Early Greece and the Mediterranean, Hoboken, Wiley Blackwell, 2020 (Blackwell Companions to the Ancient World), p. 317-348. SCODEL R., "The Erinyes and Political Anger ", in A. BETTENWORTH, J. HAMMERSTAEDT (dir.), Writing Order and Emotion. Affect and the Structure of Power in Greek and Latin Authors, Hildesheim/Zürich/New-York, Olms, 2020 (Spudasmata, 188), p. 95-105. SPINELLI E., VERDE F., «Theology », in Ph. MITSIS (dir.), The Oxford Handbook of Epicurus and Epicureanism, New York/Oxford, Oxford University Press, 2020, p. 94-117. VESPA M., «Presentifying the Divine in Ancient Greek Tales: Human Voices in Animal Bodies ", in H. SCHMALZGRUBER (dir.), Speaking Animals in Ancient Literature, Heidelberg, Universitätsverlag Winter, 2020 (Kalliope 20), p. 401-425. 